\title{
Dol heuning.
}

S. J. Naudé.

Kaapstad: Umuzi, 2021. 231 pp.

ISBN 978415210796.

S. J. Naudé se debuutkortverhaalbundel, Alfabet van die voëls (2011), is destyds deur Louise Viljoen (31-47) beskryf as kosmopolities. Dieselfde is waar van sy nuutste versameling kortverhale, Dol heuning. Verhale speel af in Suid-Afrika, Namibië, Ysland, Londen, New York, Oostenryk, Frankryk en Japan. In omtrent al hierdie verhale is daar 'n uitbeelding van die etiese aanspraak wat uitgelewerdes maak op karakters wat leef in gemak en weelde. Alhoewel dit spreek tot globale probleme, spreek hierdie tema ook op spesifieke maniere tot Suid-Afrika se uiterstes van armoede en rykdom. In Dol heuning word hierdie kwessie (die aanspraak van die weerloses) in verband gebring met ouerskap en ook spesifiek met queerheid, op 'n manier wat ek nog nie voorheen in Afrikaans raakgelees het nie.

Die oorvleueling van hierdie vier eienskappe (die aanspraak van uitgelewerdes, ouerskap, queerheid en die implikasies hiervan vir Suid-Afrika) is veral duidelik in twee verhale wat onderskeidelik in Kaapstad en Johannesburg afspeel: "Fawzi al-Junaidi" en "Die dal van die doodskaduwee". Die eerste verhaal, "Fawzi al-Junaidi", gaan oor Frans en Johannes en hulle vyfjarige seuntjie Sebastian. Eendag vertel hulle huishulp, Patience, vir Frans oor die gewelddadige homofobiese aanvalle waaronder haar seun deurgeloop het. Hierdie selfde seun was as kind, voordat Frans en Johannes deur die proses van surrogasie gegaan het om hulle eie kind te verwek, "soos hul eie kind" (17). Hierdie bewoording herinner aan Ena Jansen (25) se kritiek op die diskoers waarin huiswerkers as "soos

familie" beskryf word—soos Jansen noem, spreek die "woordjie 'soos' [...] boekdele."

Die worsteling met die besluit om 'n "eie" kind te hê in 'n wêreld wat as onherbergsaam ervaar word, en waarin daar reeds 'n oorvloed behoeftige mense is wat hulp nodig het, is nie nuut nie, en in die konteks van die Afrikaanse literatuur kan daar verwys word na Ingrid Winterbach se novelle Klaaglied vir Koos (1984, gepubliseer onder die skrywersnaam Lettie Viljoen). Dié novelle gaan oor die wroeging van 'n verteller wat as enkelmoeder probeer om haar kind groot te maak in die oorweldigende apokaliptiese atmosfeer van SuidAfrika in die 1980s, terwyl sy gereeld genader word deur hawelose mense en ander uigelewerdes wat aanspraak maak op haar versorging. Die doelbewustheid waarmee 'n homoseksuele egpaar hierdie keuse moet aanpak (en die etiese kwessies waarmee hulle moet worstel in 'n wêreld op die rand van ekologiese apokalips) is wel relatief nuut, en word ook verken in die Vlaamse skrywer Saskia de Coster se roman Nachtouders (2019)'n outobiografiese roman oor lesbiese moederskap wat op soortgelyke wyse as Dol heuning soms surrealistiese dimensies aanneem om al die vrese en onsekerhede wat met ouerskap gepaard gaan, uit te beeld. In die verhaal "Warm kosmos" in Dol heuning herinner die beskrywing van die vorm wat die karakter se doodgebore kind in 'n droom aanneem, van 'n "gefrommelde swart oorblyfsel van iets soos 'n sambreel. Of 'n dooie kraai. Of 'n pterodaktiel reguit uit die hel. Vere of seil, staalpenne gebreek soos 'n feniksskelet" (165) byvoorbeeld aan die nagmerrieagtige beelde in Amerikaanse regisseur David Lynch se film oor die vrese vir ouerskap, Eraserhead (1977).

Benewens vir die feit dat die gay egpaar in "Fawzi al-Junaidi" deur baie spesifieke sielkundige en wetenskaplike prosesse moes gaan om ouers te word, gaan die verhaal ook oor die spesifieke komplikasies van queer ouerskap deurdat die etiese aanspraak wat aan hulle gemaak word deur 'n persoon van buite hulle kerngesin, dié is van 'n gay man, uitgelewer aan die homofobie in sy spesifieke gemeenskap. Binne die queerstudies bestaan daar die konsep van "queer kinship"-die alternatiewe bande wat queer mense smee om die kerngesin, waaruit hulle dikwels verban is, te vervang en te omvorm (sien Weston). Frans se wroeging oor die (queer) kind wat hy opgegee het en aan die wêreld oorgelaat het ter wille van Sebastian kan miskien verstaan word as konflik tussen "queer kinship" en die tipe voorstedelike LGBTQ+-ouerskap wat gemodelleer is op heteroseksuele familieverhoudinge.

Dieselfde dinamika kom voor in "Die dal van doodskaduwee". Alhoewel Laura, die protagonis, 'n 
heteroseksuele enkelmoeder is, voel sy haarself ook verskeur tussen haar toewyding tot haar kind en tot Xavier/Juliette, 'n gender-ambivalente jong persoon wat klaarblyklik geen ware tuiste of familie in Johannesburg het nie. In die aanvang van "Daar is mans", wat in Londen afspeel, vind ons uit dat die hoofkarakter, Jakob, se vrou hom onlangs verlaat het, onder meer oor sy "afsydigheid" (168) teenoor sy eie kinders. Nietemin voel Jakob later in die verhaal 'n toegeneentheid teenoor Cian, 'n jong man wat deur sy ouers verjaag is as gevolg van sy homoseksualiteit. In die meeste verhale in die bundel is daar dus hierdie tipe verkenning van die grens tussen voorstedelike heteronormatiwiteit (en wat die eise daarvan aan 'n verhouding kan doen) en die alternatiewe familiestrukture wat buite dit kan bestaan.

Daar is veral twee verhale wat nie by hierdie temas aansluit nie: "Wonderwerk", en "Landskap met figure" (laasgenoemde bestaan uit drie onderafdelings: "Berg", "Vallei" en "Woestyn"). Hierdie verhale kan beskryf word as goties, in hulle uitbeelding van buitestaanders wat reis na vreemde plekke en daar ongewone en gruwelike belewenisse ervaar.

In al die verhale in die bundel, beide hierdie gotiese verhale en dié wat gaan oor ouerskap en familie, is daar' $n$ klem op die sensoriese en die onverwagte. Die maniere waarop die verhale die leser intrek, verruk en ontstel, beteken dat dit opleef tot die belofte van die bundel se treffende titel en ongewoon mooi voorblad.

\section{Geraadpleegde bronne}

Jansen, Ena. Soos familie: Stedelike huiswerkers in Suid-Afrikaanse tekste. Protea, 2016.

Viljoen, Louise. "Perspektiewe op die kosmopolitisme en transnasionalisme in S. J. Naudé se Alfabet van die voëls." Tydskrif vir Nederlands en Afrikaans vol. 21, no. 1, 2014, pp. 31-47.

Weston, Kath. Families We Choose: Lesbians, Gays, Kinship. Columbia U P, 1991.

\section{Bibi Burger}

bibi.burger@up.ac.za

Universiteit van Pretoria

Pretoria, Suid-Afrika

ORCID: http://orcid.org/0000-0002-9483-6671

DOI: https://doi.org/10.17159/tl.v58il.10898 